\title{
GENERIC ALGORITHM SOLUTION IN ESTIMATION OF THE IRON ABSORPTION POTENTIAL FROM COMPLEX SCHOOL MEALS
}

\author{
Rodica Sturza, ORCID ID: 0000-0002-2412-5874, \\ Nina Mija*, ORCID ID: 0000-0001-6531-3807, \\ Olga Deseatnicov, ORCID ID: 0000-0003-4801-8173, \\ Eugenia Covaliov, ORCID ID: 0000-0003-4574-2959, \\ Natalia Suhodol, ORCID ID: 0000-0002-5609-5139 \\ Technical University of Moldova, 168 Stefan cel Mare blvd., Chisinau, MD-2004 Republic of Moldova \\ ${ }^{*}$ Correspondent author: Nina Mija, nina.mija@toap.utm.md
}

Received: 09. 30. 2021

Accepted: 11. 02. 2021

\begin{abstract}
New analytical tools to study iron bioavailability are proposed in this article. An algorithm was devised to predict dietary iron abortion from school meals based on the contents of dietary factors that have the ability to promote or inhibit heme or non-heme iron absorption. The highest absorption rate of iron from representative meals was observed in the presence of ascorbic acid $(27,73 \%)$ or meat ingredients $(27,70 \%)$, and the lowest absorption rate - in the presence of Ca $(12,40 \%)$, tannins $(5,83 \%)$ and polyphenols $(5,36 \%)$. Relationships between quantities of total iron intake from foods (dialyzable iron, in vitro assay) and the value of nutritional factors in those are described as exponential equations allowing calculations at any stationary state. In elaborated formula the rate of iron absorbance can be predicted considering one, two or three nutritional factors at the same time. The results emphasize the fact that it is important to understand the meal composition for the correct estimation of iron bioavailability.
\end{abstract}

Keywords: absorption coefficient of iron, algorithm solution, complex school meals, gastrointestinal digestion in vitro, iron absorbance prediction, rate of iron absorbance.

List of symbols: PHT - phytates, AA - ascorbic acid, PHP - polyphenols, TN - tannins, TA tannic acid, $C a$ - calcium, MP - meat products, $R D I$ - recommended daily intake.

Rezumat. În articol sunt propuse noi instrumente analitice pentru a studia biodisponibilitatea fierului. A fost conceput un algoritm pentru a prezice aportul alimentar de fier din mesele școlare, pe baza conținutului de factori dietetici care au capacitatea de a promova sau inhiba absorbția de fier hem sau non-hem. Cea mai mare rată de absorbție a fierului din mesele reprezentative a fost observată în prezența acidului ascorbic $(27,73 \%)$ sau a ingredientelor din carne (27,70\%), iar cea mai mică rată de absorbție - în prezența Ca (12,40\%), a taninurilor (5,83\%) și polifenolilor (5,36\%). Relațiile dintre aportul total de fier din alimente (fier dializabil, testări in vitro) și valoarea factorilor nutriționali sunt descrise ca ecuații 
exponențiale, care permit calcule în orice stare staționară. În formula elaborată, rata de absorbție a fierului poate fi prezisă luând în considerare unu, doi sau trei factori nutriționali concomitent. Rezultatele subliniază faptul că este important să înțelegem compoziția mesei pentru estimarea corectă a biodisponibilității fierului.

Cuvinte cheie: coeficient de absorbție a fierului, algoritm, mese școlare complexe, digestie gastrointestinală in vitro, predicție absorbție a fierului, rata de absorbție a fierului.

Lista simbolurilor: PHT - fitati, AA - acid ascorbic, PHP - polifenoli, TN - taninuri, TA - acid tanic, Ca - calciu, MP - produse din carne, RDI - aport zilnic recomandat.

\section{Introduction}

Iron performs many physiological functions in the human body, one of the most obvious being the function of erythrocyte formation and the transport of oxygen to organs and tissues) $[1,2]$. Iron in the human body is an integral part of many enzymes and proteins that are necessary for metabolic processes - the destruction and utilization of toxins, cholesterol metabolism, and the conversion of calories into energy [3 - 5]. It also helps the body's immune system to deal with aggressors [ 6, 7].

Currently, population of the Republic of Moldova is having products of vegetable origin from which iron is insufficiently assimilated [8-9]. For this reason, even in the conditions of sufficient nutrition, the majority of the population suffers from a chronic deficiency of iron and calcium, which causes the body predisposition to nutritional diseases [10]. According to statistical data, the incidence of blood and hematopoietic diseases in the Republic of Moldova per 1000 inhabitants in the 2010-2020 years varied between 48,1 and 50,1 , data that far exceed this index in European countries [11].

The greatest risk for iron deficiency are groups of adolescents (12 - 15 years old), followed by children (6 - 8 years old) [12 - 14]. The results of the laboratory investigations reveal the presence of hypohemoglobinemia up to $10 \%$ of the norm for $43,5 \%$ of the total number of investigated children, up to $20 \%-18,3 \%$ and up to $20-30 \%$ - for about $1 \%$ [15].

The absorption of iron from food rations depends not only on the total iron content in them, but also on the ratio of animal and plant products, as well as on substances that enhance or inhibit its absorption in the gastrointestinal tract. The absorption of iron from predominantly plant-based diets is usually low, since they contain substances that inhibit the absorption of this macronutrient - phytates, tannins, calcium salts $[16,17]$.

A sufficient amount of meat and fish, which contain organic heme and non-heme iron, as well as the nutritional factors that increase the probability of its absorption are the guarantee of optimal absorption of iron.

Unfortunately, there are currently no practical models for predicting iron absorption potential based on dietary nutritional composition.

\section{Materials}

This study was conducted in order to estimate the level of total iron intake and dialyzable iron by intestinal digestion in vitro of the food rations of institutionalized children as well as to estimate the impact of enhancing and inhibiting factors on iron absorption that are present in the food rations [18]. The steps of providing this research are the following:

Step 1. In vitro estimation of the bioavailability of iron from the complex ration of institutionalized children, aged 7 - 16 years. 
Step 2. Evaluation of anti-nutritional factors that must have been taken into consideration.

Step 3. Elaboration of the algorithm that would allow the estimation of the rate of absorption of hemic and non-hemic iron from foods.

The investigations were carried out within 12 days in order to take into account daily variation.

\section{Research methods}

Samples preparation. The foods were homogenized and after that they were exposed to determination of nutritional compounds or exposed to simulating conditions of digestion. The foods from representative meals were mixed with distilled water and homogenized in a blender to a creamy consistency, so as to give approximately $10 \mathrm{~g}$ dry matter/l00 $\mathrm{g}$ homogenate.

The Monsen simulation method was applied for homogenates of foods to reproduce the digestive conditions on the stomach level (in the presence of pepsin, $150 \mathrm{mg} / 100 \mathrm{~g}$ substrate, digestive strength activity of $250000 \mathrm{FCC} \mathrm{un} / \mathrm{mg}$, at $\mathrm{pH}=2(0,01 \mathrm{~N}$ sol. $\mathrm{HCl}))$ and then on the intestine level (in the presence of trypsin, $150 \mathrm{mg} / 100 \mathrm{~g}$ substrate, digestive strength activity of $600 \mathrm{E} \mathrm{un} / \mathrm{mg}$, at $\mathrm{pH}=8 . .8,2\left(0,08 \mathrm{~N}\right.$ sol. $\left.\mathrm{NaHCO}_{3}\right)$ [19].

The steps of the simulation of the stomach or intestine digestion had duration of 2 hours each one, were carried out at $37 \pm 1{ }^{\circ} \mathrm{C}$ with stirring at $60 \mathrm{~g}^{-1}$. The aliquots for the analysis were taken every 30 min. of the digestion process.

Each aliquot of partially digested foods was subjected to centrifugation (10 min. at $6000 \mathrm{~g}^{-1}$ ), then the supernatant (about $1 \mathrm{ml}$ ) was analyzed to quantify the amount of dialyzed products - iron, calcium, soluble phytates.

Investigations of nutritional factors. The soluble $\mathrm{Fe}$ in prepared samples was determined by the spectrophotometric method at $535 \mathrm{~nm}$, using as an extraction medium a mixture of hydroxylamine and trichloroacetic acid and as the chromogenic reagent the bathphenanthrolene-disulfonic acid disodium salt (BPDS) [20]. The total iron content of samples was determined after solid or liquid mineralization of the samples [21, 22].

The phosphorus content in the samples was determined in the reaction with ammonium molybdate-vanadate at $440 \mathrm{~nm}$ [23]. The content of phytates in the products of vegetal origin was determined using a recalculation factor of 1:3,55 [24]. The quantity of dialyzed phytates was determined in correlation with rate of accumulation of soluble Ca during gastrointestinal digestion.

The total Ca content was determined by atomic absorption spectroscopy method after sample mineralization [25]. The limit of detection of the method is $0,2 \mathrm{mg} \mathrm{Ca} / \mathrm{kg}$ of sample, the linearity range - 0,2-200 $\mathrm{mg} \mathrm{Ca} / \mathrm{kg}$ of sample. Determination of soluble Ca content was performed by titration with Trilon B [26]. The ascorbic acid content was determined by titration with 2,6-dichlorphenol-indophenol [27].

The calculation of nutrition factors present in the children meals were performed using Excel software.

Statistical analysis. Experimental testing was carried out in triplicate for each sample and standard. Descriptive statistical analysis was performed using Excel software for calculating the means and standard deviations. The mathematical expression of influence of nutritional data of meals on the value of coefficient of iron absorbance was obtained using SPSS (version 13.0 Windows program). 


\section{Results and discussions}

Nutritional value of complex meals. The nutritional study highlighted the fact that the average calorific value for the examined 12 days was of $2069 \mathrm{kcal} /$ day (Table 1), which represents $82,8 \%$ of the average daily requirement of $2500 \mathrm{kcal} / \mathrm{day}$. The content of macronutrients, according to the performed calculations for this period, may be distributed as follows: proteins - 71,39 $\mathrm{g} /$ day, i.e. $79,3 \%$ compared to the physiological norm (on average $90 \mathrm{~g} /$ day); lipids - 60,36 g / day, i.e. 67\% compared to the recommended norm; sugars - 335,4 g / day, i.e. 93,17\% (on average $360 \mathrm{~g} /$ day). The average daily intake of iron calculated from recipes was $17,2 \mathrm{mg}$ Fe /day, what constitutes $95,6 \%$ of the recommended intake (18 mg Fe /day). But the average content of total iron, determined in the daily rations of institutionalized children by experimental techniques constitutes only 9,66 mg Fe /day, which covers only $53,75 \%$ of the recommended norm.

Table 1

Level of total iron content in the ration of institutionalized children aged 11 - 17 years in Moldova

\begin{tabular}{ccccc}
\hline \multirow{2}{*}{$\begin{array}{c}\text { Monitorized } \\
\text { days }\end{array}$} & $\begin{array}{c}\text { Energetic } \\
\text { value }\end{array}$ & \multicolumn{2}{c}{ Total iron content (mg/day) } & Total iron from \\
\cline { 3 - 4 } & (kcal/day) & Calculated & Experimental & RDI (\%) $^{\mathbf{2}}$ \\
\hline 1 & 1911,9 & 15,44 & $9,54 \pm 0.03$ & $53,0 \pm 0.2$ \\
\hline 2 & 2006,9 & 16,73 & $10,11 \pm 0.07$ & $56,6 \pm 0.4$ \\
\hline 3 & 1767,0 & 13,05 & $8,19 \pm 0.06$ & $45,5 \pm 0.3$ \\
\hline 4 & 1995,0 & 14,63 & $9,22 \pm 0.05$ & $51,2 \pm 0.3$ \\
\hline 5 & 2392,7 & 18,23 & $11,75 \pm 0.09$ & $65,3 \pm 0.5$ \\
\hline 6 & 2459,9 & 21,25 & $12,09 \pm 0.08$ & $67,2 \pm 0.4$ \\
\hline 7 & 1997,8 & 17,03 & $9,75 \pm 0.06$ & $54,2 \pm 0.3$ \\
\hline 8 & 2016,5 & 19,05 & $9,92 \pm 0.07$ & $55,1 \pm 0.4$ \\
\hline 9 & 1876,4 & 15,74 & $8,14 \pm 0.05$ & $45,2 \pm 0.3$ \\
\hline 10 & 1991,2 & 18,05 & $9,37 \pm 0.07$ & $52,1 \pm 0.4$ \\
\hline 11 & 2005,6 & 17,63 & $8,89 \pm 0.06$ & $49,4 \pm 0.3$ \\
\hline 12 & 2411,5 & 19,74 & $8,95 \pm 0.05$ & $49,7 \pm 0.3$ \\
\hline Mean & 2069,0 & 17,20 & $9,66 \pm 0.09$ & $53,7 \pm 0.5$ \\
\hline
\end{tabular}

Note. Recommended energetic value for girls - $2400-2700 \mathrm{kcal} /$ day, boys $2500-2700 \mathrm{kcal} /$ day [39]. Recommended daily iron intake $-18 \mathrm{mg} /$ day, or 7,2 mg Fe/1000 kcal [28].

Research done in the conditions of gastrointestinal digestion in vitro showed that the level of dialyzed iron (i.e. available for gastrointestinal absorption) reached a value of $1,84 \mathrm{mg} /$ day (Table 2 ), which constitutes $18,6 \%$ compared to total iron.

An important indicator of rational nutrition is the ratio of whatever macronutrients to energy value of meal, in this case - 7,2 mg Fe /1000 kcal [28]. According to the experimental determinations of the analyzed meals, this indicator was relatively low, about $4,67 \mathrm{mg} F e / 1000 \mathrm{kcal}$. In the same time the level of dialyzable iron, experimentally determined after gastrointestinal digestion research in vitro is extremely low and constitutes only $0,89 \mathrm{mg}$ Fe $/ 1000$ kcal. 
Level of dialyzed iron content in the ration of institutionalized children aged 11-17 years in Moldova

\begin{tabular}{cccccc}
\hline \multirow{2}{*}{$\begin{array}{c}\text { Monitorized } \\
\text { days }\end{array}$} & Breakfast & Lunch & Dinner & Per day & $\begin{array}{c}\text { Dialyzed } \\
\text { iron (\% } \\
\text { from total } \\
\text { iron) }\end{array}$ \\
\hline 1 & $0,26 \pm 0,02$ & $0,87 \pm 0,03$ & $0,62 \pm 0,05$ & $1,75 \pm 0,05$ & 18,3 \\
\hline 2 & $0,31 \pm 0,05$ & $0,87 \pm 0,07$ & $0,81 \pm 0,05$ & $1,99 \pm 0,07$ & 19,7 \\
\hline 3 & $0,29 \pm 0,05$ & $0,50 \pm 0,02$ & $0,37 \pm 0,05$ & $1,16 \pm 0,05$ & 14,2 \\
\hline 4 & $0,34 \pm 0,06$ & $0,79 \pm 0,06$ & $0,82 \pm 0,05$ & $1,95 \pm 0,06$ & 21,1 \\
\hline 5 & $0,62 \pm 0,05$ & $0,76 \pm 0,05$ & $0,69 \pm 0,05$ & $2,07 \pm 0,05$ & 17,6 \\
\hline 6 & $0,42 \pm 0,05$ & $0,68 \pm 0,03$ & $1,05 \pm 0,05$ & $2,12 \pm 0,07$ & 17,5 \\
\hline 7 & $0,53 \pm 0,06$ & $0,63 \pm 0,06$ & $0,69 \pm 0,05$ & $1,85 \pm 0,06$ & 18,9 \\
\hline 8 & $0,37 \pm 0,05$ & $0,38 \pm 0,03$ & $0,43 \pm 0,05$ & $1,27 \pm 0,05$ & 12,8 \\
\hline 9 & $0,45 \pm 0,03$ & $0,80 \pm 0,05$ & $0,67 \pm 0,06$ & $1,92 \pm 0,06$ & 23,6 \\
\hline 10 & $0,49 \pm 0,05$ & $0,99 \pm 0,01$ & $0,57 \pm 0,05$ & $2,05 \pm 0,05$ & 21,8 \\
\hline 11 & $0,27 \pm 0,02$ & $0,42 \pm 0,04$ & $0,87 \pm 0,04$ & $1,56 \pm 0,04$ & 17,5 \\
\hline 12 & $0,52 \pm 0,07$ & $0,70 \pm 0,03$ & $0,67 \pm 0,05$ & $1,88 \pm 0,07$ & 21,1 \\
\hline Mean & $\mathbf{0 , 4 0 \pm 0 , 0 4}$ & $\mathbf{0 , 6 9} \pm 0,04$ & $\mathbf{0 , 6 8} \pm 0,04$ & $\mathbf{1 , 8 4} 00,07$ & 18,6 \\
\hline
\end{tabular}

Note. Dialyzed Fe was determined after 4 hours of digestion in vitro (2 hours of modeled gastric digestion in the presence of pepsin at $\mathrm{pH}=2$, and 2 hours of modeled intestinal digestion in the presence of trypsin at $\mathrm{pH}=8$ ).

According to the nutritional calculations, the average content of phytic phosphorus, recalculated in phytic acid was $1,85 \mathrm{~mol} /$ day (Table 3 ). After 4 hours of gastrointestinal digestion in vitro only $16,35 \%$ of the presented phytates were degraded due to enzymolysis in the presence of gastrointestinal enzymes. This explains also the very low percentage of dialyzable calcium $(5,4 \%)$, which confirms the fact that the stability of Ca phytates compounds is very high [29]. The analysis of the obtained data denotes the need for improving the nutrition of the institutionalized children in accordance with the nutritional principles [30], especially for the compartment of macroelements (Fe and $\mathrm{Ca}$ ). Achievement of this goal involves actions for increasing the contribution of essential macro- and microelements as well to ensure their bioavailability [31, 32]. In particular, it is recommended to use in children's nutrition foods that are rich in iron (meat, fish and beans). Also, fortified products with an increased bioavailability of iron can be used [33, 34].

The level of absorption rate of iron in foods is influenced by the individual status of the organism in the iron, by the content of the iron and its structure forms (hemic and nonhemic iron) in the ration, as well as by all the nutritional factors, present in the ration.

It is known that some dietary factors (free amino acids, proteins of animal origin) have a positive influence on the bioavailability of iron in foods, while other factors (phytates, tannins and other polyphenols, oxalates, calcium) possess the ability to inhibit absorption of dietary iron [35 - 37]. It is also necessary to take into account the interactions of various factors present in the ration. Thus, the working hypothesis was formulated as follows - the degree of absorption of iron in food is the result of the action of all the factors present in food. 
Impact of anti-nutrients (phytates, calcium) on the level of soluble iron content/day of the ration of institutionalized children aged 11-17 years in Moldova

\begin{tabular}{|c|c|c|c|c|c|c|c|c|c|c|}
\hline \multirow{2}{*}{$\begin{array}{c}\text { Monito } \\
\text {-rized } \\
\text { days }\end{array}$} & \multicolumn{3}{|c|}{$\begin{array}{c}\text { Calculated } \\
\text { macronutrients }(g)\end{array}$} & \multicolumn{3}{|c|}{$\begin{array}{c}\text { Calculated } \\
\text { micronutrients }(\mathrm{mg})\end{array}$} & \multirow{2}{*}{$\begin{array}{l}\text { Phyti- } \\
\text { cal P } \\
\text { (mg) }\end{array}$} & \multirow{2}{*}{$\begin{array}{l}\text { Total } \\
\text { phy- } \\
\text { tates } \\
\text { (mol) }\end{array}$} & \multicolumn{2}{|c|}{$\begin{array}{c}\text { After } 4 \text { hours of } \\
\text { gastrointestinal digestion in } \\
\text { vitro }\end{array}$} \\
\hline & $\begin{array}{l}\text { Pro- } \\
\text { teins }\end{array}$ & Fats & Sugars & $\mathrm{Ca}$ & $\mathrm{Fe}$ & $\mathbf{P}$ & & & $\begin{array}{l}\text { Dialysed Fe } \\
\text { (\%) }\end{array}$ & $\begin{array}{c}\text { Hydrolyzed } \\
\text { phytates (\%) }\end{array}$ \\
\hline 1 & 64,69 & 3,82 & 336,42 & 7 & 44 & 103 & 2,6 & 1,5 & $18,3 \pm 0,03$ & $15,75 \pm 0,09$ \\
\hline 3 & 57,11 & 37,9 & כנו, & 604,4 & 4,63 & 963,3 & 924,8 & 1,4 & $14,2 \pm 0,01$ & $17,29 \pm 0,11$ \\
\hline 5 & 86,42 & 100,9 & 347,16 & 863,2 & 18,23 & 1565,2 & 1502,6 & 2,2 & $17,6 \pm 0,02$ & $14,83 \pm 0,13$ \\
\hline 7 & 100,5 & 61,84 & & 1003 & 19,74 & 1799,9 & 77 & & $19,7 \pm 0,03$ & $21,37 \pm 0,15$ \\
\hline 9 & 62 & 5 & 27,2 & 627,4 & 15,74 & 125 & & & & \\
\hline 11 & 56,9 & 70,3 & 327,6 & 511,1 & 16,73 & 1046,0 & 1004,2 & 1,52 & $17,5 \pm 0,02$ & $12,96 \pm 0,08$ \\
\hline Mean & 71,38 & 60,36 & 335,4 & 690,1 & 16,75 & 1042,7 & 1226,4 & 1,85 & $18,48 \pm 0,03$ & $16,35 \pm 0,15$ \\
\hline
\end{tabular}

The absorption coefficient of the iron was analyzed in relation to the reference samples, free of anti-nutrients, in which the degree of absorption of the iron was considered maximum - of $22,1 \%$ with reference to the total iron content [38]. Based on the research carried out, on the analysis of rations of institutionalized children, the authors developed an algorithm, aimed to highlighting the influence of the various compounds present in the ration on the rate of iron solubility in the gastrointestinal media.

Influence of phytates. In order to evaluate the impact of phytates present in foods on the absorption coefficient of iron, the relationship between the iron solubility of each representative sample and the total iron content, the total phytate content, and also the rate of enzymolysis of the phytates during gastrointestinal digestion was established for the examined samples (12 days $\cdot 3$ meals $=48$ ) [39]. The mathematical analysis was performed by extrapolation of these functions to the null content of the phytates in the representative meal, where iron absorption is considered optimal $(22,1 \pm 0.18) \%$.

Comparison of obtained data allowed establishing of the following relationship between the coefficient of iron absorption and phytates content of the food:

$$
\mathrm{K}_{\mathrm{abs} .}(\mathrm{Fe})=10^{-0,3 \cdot \log \left(1+0,2833 \cdot \mathrm{C}_{\mathrm{PHT}}\right)}
$$

where $\mathrm{C}_{\mathrm{PHT}}$ is the content of phytates in the representative meals, expressed in $\mathrm{mg}$.

The value of correlation coefficient was estimated to be: $r^{2}=0,926(n=48)$.

Thus, the effect of phytates on the absorption coefficient of iron from foods is significant. If the content of the phytates, for example, in a representative meal is null, such as $\mathrm{K}_{\mathrm{abs} .}(\mathrm{Fe})=1$, the absorption of iron can be considered to be $22,1 \%$. If $353 \mathrm{mg}$ of phytates are consumed (from bread, for example), and the rate of hydrolyzed phytates does not exceed $15 \%$, in this case $C_{P H T}$ will be $300 \mathrm{mg}$. Substituting this value into equation (1), we obtain:

$$
\mathrm{K}_{\text {abs. }}(\mathrm{Fe})=10^{-0,3 \cdot \log \left(1+0,2833 \cdot \mathrm{C}_{\mathrm{PHT}}\right)}=10^{-0,3 \cdot \log (1+0,2833 \cdot 300)}=0,2637 .
$$

Thus, the absorption potential of iron from the representative meal will constitute $22,1 \cdot 0,2637=5,83 \%$ of the total ingested quantity of iron. Obviously, the algorithm does not take into account the influence of the iron status of the organism, a factor that has a decisive influence on the absorption of iron from foods. 
Influence of ascorbic acid (AA). According to the authors [40], the promoter effect of ascorbic acid is much more prominent in the presence of iron absorption inhibitors, especially phytates and polyphenols. Thus, the addition of $100 \mathrm{mg} \mathrm{AA}$ in beverages, in the presence of tea tannins increased the iron absorption by 4,14 times, and also, in the presence of phytates the absorption of iron is increased by 3,14 times. But the addition of a similar amount of AA to a representative meal (which contained meat, potatoes and milk, but without of these inhibitors of iron absorption) increased iron absorption only with $67 \%$. The addition of $50 \mathrm{mg}$ of $\mathrm{AA}$ in wheat flour rolls increased the average iron absorption from 22,4 to $37,6 \%$ Investigations have been conducted in vivo with the labeled atoms of iron.

These bibliographic data indicate that the promoter effect of AA is strongly correlated with the factors present in the diet. As an antioxidant, AA facilitates the reduction of ferric iron into ferrous iron, which has much weaker chelating properties than ferric iron with reference to polyphenols and phytates present in the diet [41]. Therefore it is obvious that the promoting effect of AA will be more significant, since the binding rate of iron by chelating inhibitors will be higher. These regularities were taken into account for the formulation of the algorithm that describes the promoter effect of $A$ in the presence of phytates. Also, for the elaboration of the algorithm the following conditions have been met:

- $\quad$ in the absence of AA inhibitors, a promoter effect is proportional to the administered dose:

$$
\mathrm{K}_{\mathrm{abs} .}(\mathrm{Fe})=1+0,01 \cdot \mathrm{C}_{\mathrm{AA}}
$$

where $C_{A A}$ represents the $A A$ content, expressed in $\mathrm{mg} /$ representative meal [42].

- in the presence of phytates, the promoter effect of $A A$ is manifested more significantly, when the phytate content is higher.

Because in the analyzed representative meals the phytates were present in variable quantities, the data were analyzed specifically for such cases. The regression lines that describe this relationship have a different linear slope depending on the logarithm of $C_{\text {AA. }}$ The correlation coefficients $\left(r^{2}\right)$ ranged from 0,837 to $0,877(n=48)$. The analysis of the obtained regression equations allowed us to establish the following equation, which expresses the relation between the absorbability of the iron on the one hand and the AA content and of the phytates on the other:

$$
\mathrm{K}_{\mathrm{abs} .}(\mathrm{Fe})=0,01 \cdot\left[1+0,01 \cdot \mathrm{C}_{\mathrm{AA}}+\log \left(1+0,2833 \cdot \mathrm{C}_{\mathrm{PHT}}\right)\right] \cdot 10^{0,8875 \cdot \log \left(1+\mathrm{C}_{\mathrm{AA}}\right)}
$$

The correlation coefficient for the obtained equation had the value: $r^{2}=0,995(n=48)$. The promoter effect of AA described by equation (3), was similar for the case of the presence in the meals of meat products (that contain hemic iron) and milk products (that contain calcium).

To compare the promotional effect of AA in the absence or presence of phytates, we admit that a representative meal contained $30 \mathrm{mg}$ of AA (from fresh fruit, fruit juices). In the absence of phytates and other iron absorption inhibitors, the iron absorption coefficient is determined from the relationship (2).

$$
\mathrm{k}_{\mathrm{abs}}(\mathrm{Fe})=1+0,01 \cdot \mathrm{C}_{\mathrm{AA}}=1+0,01 \cdot 30=1,3 \text {. }
$$

Thus, the bioavailability of iron from a complex meal, but that is lacking in antinutritional factors, in the presense of AA will constitute: $22,1 \cdot 1.3=27,73 \%$. 
For comparison, if the concomitant presence of $353 \mathrm{mg}$ of phytates is allowed, where the rate of enzymatic dephosphatization in the gastrointestinal tract does not exceed $15 \%$, the iron absorption coefficient calculated according to the relationship (3) will be:

$$
\mathrm{k}_{\mathrm{abs} .}(\mathrm{Fe})=0,01 \cdot[1+0,01 \cdot 30+\log (1+0,2833 \cdot 300)] \cdot 10^{0,8875 \cdot \log (1+30)}=0,4258 ;
$$

which means that $22,1 \cdot 0,4258=9,41 \%$ of the total iron present in the food intake of a representative meal will be absorbed.

Comparing this value with the absorption coefficient, obtained in the presence of the same quantities of phytates, but in the absence of $A A\left(k_{a b s .}(F e)=0,2637\right)$, it becomes obviously that the promoter effect of AA is especially important in the presence of inhibitors:

$$
\frac{0,4258}{0,2637}=1,615 \text { (for } 30 \mathrm{mg} \text { of } \mathrm{AA} \text { and } 353 \mathrm{mg} \text { of phytates). }
$$

In the absence of inhibitors, the protomotor effect of the same amounts of AA will be of 1.3 times more evident.

A practical problem, related to the application of this algorithm, resides in the difficulty of estimating the AA content at the time of consumption, because the method and duration of applied heat treatments significantly influence the AA content. As a rule, the table data regarding to the composition of foods are used for the assessment of AA content, although the differences between the experimental data and the table data are significant.

Influence of polyphenols. The inhibitory effect of tea, coffee, red wine on iron absorption is confirmed in several bibliographic studies [10, 43]. This effect is attributed to the presence of polyphenols. Gallium groups with the 3 adjacent hydroxyl groups, specific for polyphenols, are considered the main structures, which fix iron by forming chelates [44]. In particular, ferric iron is fixed, which explains the role of AA in diminishing the inhibitory effect phenolic compounds on iron absorption.

The inhibition of the absorption of iron by coffee is attributed, in particular, to the important content of chlorogenic acid in this product, although the action of this compound is less marked than of the gallium groups. It is estimated that the equimolar amounts of gallic and chlorogenic acids have a relative effect of inhibition of iron ansorbtion of 6:1. Thus, it is stated that a $200 \mathrm{ml}$ cup of tea reduces the absorption of iron in consumed foods on average by $75-80 \%$. A $100 \mathrm{ml}$ cup of coffee reduces iron absorption by an average of $60 \%$. When tea or coffee is served at the same meal with a $100 \mathrm{~g}$ portion of meat, the iron inhibiting effect is reduced by $50 \%$.

The lower inhibitory effect of coffee in comparison to the action of tea is explained by the fact that coffee considerably stimulates gastric secretion (production of $\mathrm{HCl}$ ). The research bazed on iron absorption in individuals with hypochlorhydria indicates a much stronger inhibitory effect of the coffee (the rate of absorption of iron was 0,19 to 0,39 - for healthy people) [12]. In order to evaluate the effect of tea or coffee on the absorption of iron, it has established a factor equivalent of $15 \mathrm{mg}$ of tannic acid (TA) for a cup of ordinary coffee (with or without milk) and $30 \mathrm{mg}$ TA for a cup of tea.

Taking into acount this factors, as well as the presence of meat or fish products in the ration ( $m_{M P+F P}, g$ ), the effect of polyphenols on the absorption coefficient of iron in foods can be expressed by the empirical relation:

$$
K_{\text {abs. }}(F e)=\left(1+0,01 \cdot m_{M P+F P}\right) \cdot 10^{\left.0,4515-\left[0,715-0,1825 \cdot \log \left(1+C_{A A}\right)\right] \cdot \log \left(1+A_{T A}\right)\right]}
$$


where the content of $C_{A A}$ and $C_{T A}$ is expressed in $\mathrm{mg} / \mathrm{meal}$. For the examined cases $(\mathrm{n}=48)$, the correlation index was: $\mathrm{r}^{2}=0,978$.

The deduced empirical relation allows to estimate the summary effect of promoters (meat and fish products, $\mathrm{AA}$ ) and inhibitors (tannic acid equivalent of polyphenols) present in a representative meal on the absorption coefficient of iron from foods. For example, if $50 \mathrm{~g}$ of meat is consumed at the same time with $353 \mathrm{mg}$ of phytates with hydrolysis rates of $15 \%$ (a slice of bread), $30 \mathrm{mg}$ of AA and $30 \mathrm{mg}$ of TA (a cup of tea), then in this case the absorption coefficient of iron will have the value:

$$
\mathrm{k}_{\mathrm{abs} .}(\mathrm{Fe})=(1+0,01 \cdot 50) \cdot 10^{0,4515-[0,715-0,1825 \cdot \log (1+30)] \cdot \log (1+30)]}=0,927 ;
$$

that means, that the absorption rate of iron can be evaluated at $20,5 \%$.

In the absence of $\mathrm{AA}$, but in the presence of meat and fish products the absorption coefficient of iron will constitute 0,628 (the calculation is performed based on the same equations (4).

In the absence of AA, but in the presence of meat and fish products, we will have:

$$
\mathrm{k}_{\mathrm{abs} .}(\mathrm{Fe})=(1+0,01 \cdot 50) \cdot 10^{0,4515-0,715 \cdot \log (1+30)}=0,3614 \text {, }
$$

that means, that the absorption rate of iron can be evaluated at $\approx 8 \%$. Thus, the promoter effect of AA in the presence of polyphenols (TA) is very significant and constitutes $\frac{0,927}{0,3614}=$ 2,565 .

In the absence of both iron promoters - AA and meat and fish products, the absorption coefficient of iron in foods, consumed at the same time with a cup of tea, will be even lower:

$$
\mathrm{k}_{\text {abs. }}(\mathrm{Fe})=10^{0,4515-0,715 \cdot \log (1+30)}=0,2428 ;
$$

that means, that the absorption rate of iron can be estimated at $5,36 \%$.

This algorithm allows to take into account both the presence of inhibitors factors, and promoters.

Influence of calcium. The inhibitory effect of calcium on the absorption rate of iron from foods with complex structure has been reported in a considerable number of studies [45 - 47]. As the nature of the inhibitory effect of calcium on the iron absorption from foods was not exactly set, some authors have assumed that in the case of complex foods the formation of mixed iron and calcium chelated compounds are taken place (the last being more abundant). It is also assumed that the negative effect on iron absorption manifested by $\mathrm{Ca}$ is due to the inhibition of iron absorption by enterocytes in the presence of a significant amount of $\mathrm{Ca}$. It is considered that the abundance of calcium in meals is also associated with a decrease in the amount of serum ferritin, which produces a great biological relevance regarding to the iron absorption potential [48].

The effect of calcium on the absorption coefficient of iron in foods can be expressed by the empirical relation:

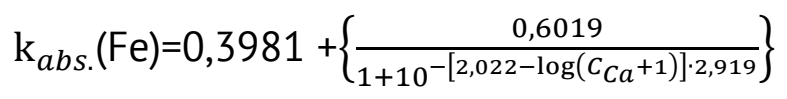

If $300 \mathrm{mg}$ of $\mathrm{Ca}$ is consumed in a representative meal, then the absorption coefficient of iron will be:

$$
\mathrm{k}_{\mathrm{abs} .}(\mathrm{Fe})=0,3981+\left\{\frac{0,6019}{1+10^{-[2,022-\log (300+1)] \cdot 2,919}}\right\}=0,562 ;
$$


That means, that the rate of iron absorbance can be evaluated at $12,4 \%$. Concentration of calcium is expressed in $\mathrm{mg} /$ representative meal.

If the consumption of $\mathrm{Ca}$ in a representative meal is of $500 \mathrm{mg}$, then:

$$
\mathrm{k}_{\mathrm{abs} .}(\mathrm{Fe})=0,3981+\left\{\frac{0,6019}{1+10^{-[2,022-\log (500+1)] \cdot 2,919}}\right\}=0,404 ;
$$

which corresponds to an iron absorption rate of $8,93 \%$.

The inhibitory effect of calcium on iron absorption is striking, especially at high calcium concentrations. At low concentrations of calcium in meal (100-200 mg), the inhibitory effect of calcium is non-significant [49].

Influence of meat and fish products. Many researchers showed that meat and fish products increase the absorption of non-hemic iron. Currently, the promotional mechanism of these products is not completely elucidated, as well as the magnitude of this effect for different product groups. According to the study [50], the absorption rate of iron from foods, depending on the meat and fish content of the meal (in the absence of iron absorption inhibitors), is expressed by the linear relationship:

$$
\mathrm{k}_{\mathrm{abs}}(\mathrm{Fe})=1+0,00628 \cdot \mathrm{m}_{\mathrm{MP}+\mathrm{FP}}
$$

where, $\mathrm{m}_{\mathrm{MP}+\mathrm{FP}}$ reprezents the sumarazed quantity of meat and fish products (g) /reprezentative meal.

Because of, in the examined case meat and fish products were served as a complex meals (in the presence of phytates in bread rolls), the combined effect of these two factors on the absorbability of iron was analyzed. The combined effect of these two factors is expressed by the algorithm:

$$
\mathrm{k}_{\mathrm{abs}}(\mathrm{Fe})=1+0,00628 \cdot \mathrm{m}_{\mathrm{MP}+\mathrm{FP}} \cdot\left(1-0,0017 \cdot \mathrm{C}_{\mathrm{PHT}}\right) \text {; }
$$

So, the promotional effect of meat and fish products is noticeable also in the presence of phytates $\left(r^{2}=0,976 ; n=48\right)$. If $50 \mathrm{~g}$ of meat or fish are consumed, then the absorption coefficient of iron in the absence of phytates will be of:

$$
\mathrm{K}_{\mathrm{abs} .}(\mathrm{Fe})=1+0,00628 \cdot 50=1,314 \text {; }
$$

which corresponds to an iron absorption rate of $27,7 \%$;

In the presence of phytates ( $353 \mathrm{mg}$, with the hydrolysis rate of $15 \%$ ), the absorption of iron will be:

$$
\mathrm{K}_{\mathrm{abs}}(\mathrm{Fe})=1+0,00628 \cdot 50 \cdot(1-0,0017 \cdot 300)=1,154 ;
$$

which corresponds to an iron absorption rate of $24,3 \%$.

For performing the calculations according to this algorithm, it is used a recalculation proportion - $1 \mathrm{~g}$ of raw meat corespond to $1,3 \mathrm{~g}$ of heat treated meat [51].

\section{Conclusions}

Suggestions for applying the algorithm for assessing the bioavailability of iron in complex foods. In order to determine the absorption coefficient of iron from a representative meal, it should be proceed in the following way. The average iron absorption of $22.1 \%$ is considered as a basic factor. This data is multiplied and influence by the presence of one or more dietary factors specific for foods: phytates factor, AA factor, polyphenols factor, Ca factor and MP factor. The obtained values will represent the percentage of bioavailability of 
iron in foods (or the probable absorption). Subsequently this quantity data might be adjusted to the iron status corresponding to the absorption dose of the experimental sample.

The algorithm can be used to evaluate the iron content availability in foods, for example, from school and students' lunches, for hospitalized persons, for performance athletes, for people doing their military service, etc. The algorithm allows to transfer the data from the aria of general nutritional research to amounts of absorbable iron. The main requirement for these calculations is the presence of accurate and detailed information on the nutritional composition of the meals for a sufficient period of time (12 - 14 days).

The algorithm allows to estimate the presumed effects of some dietary changes, for example fortification of the diet with iron, increased consumption of fruits and vegetables, the degree of iron extraction from various types of flour used in the bakery industry, etc. Also, the algorithm allows to estimate the degree of coverage of nutritional requirements for different population groups, groups that are feeding on different styles (vegetarians compared to full diet), that would allow to elaborate reasoned nutritional recommendations.

Impediments in using. The basic difficulties in applying of this algorithm lie in the following. A practical problem, which involves certain difficulties, is the estimation of the AA content at the time of consumption, since the type of process and the duration of the applied heat treatment significantly influence the AA content. Phytates have a marked influence on the absorbability of iron, even in relatively small quantities. Progressive dephosphating of phytates which occurs during food processing, changes their impact on the iron absorption coefficient. Thus, if only estimative calculations will be taken into account, given on the initial content of the phytates in the original foods, data with different degree of correlation will be obtained.

In order to outline these practical problems, supplemented data must be used, that indicate both the content of phytates and the content of polyphenols in foods of vegetable origin, expressed in equivalents of elementar components - phytic acid, tannic acid, chlorogenic acid.

Acknowledgment: The research was funded by State Project 20.80009.5107.09 "Improving of food quality and safety through biotechnology and food engineering", running at Technical University of Moldova.

\section{References}

1. Abbaspour N., Hurrell R. Review on iron and its importance for human health. In: J. Res. Med. Sci., 2014, V. 19, No. 2, p. 164-174.

2. Navas-Carreros S., Perez-Granados A., Sarria B. Iron absorbtion from meat pate fortified with ferric pyrophosfate in irondeficient woman. In: Nutrition, 2009, V. 25, p. 20-24.

3. Hausmann A., Pantopoulas K. Iron regulatory protein. In: Biochemical Aspects and Human Nutrition. Monreal: Ed.: Rossi, L., 2010. - p. 101-126.

4. N. Papanicolaou G., Pantopoulas K. Iron metabolism and toxicity. In: Toxicology and Applied Pharmacology, 2005, V. 202, No. 8, pp. 199-211.

5. Sandstead H. Causes of iron and zinc deficiencies and their effects on brain. In: J. Nutr., 2010, V. 130, No. 2S, p. 347S-349S.

6. Sheftel A.D., Mason A.B., Ponka P. The long history of iron in the Universe and in health and disease. In: Biochimica and Biophysica Acta, 2012, V. 1820, p. 161-187.

7. Walker E.M. Effects of the iron overload on immune system. In: An. Clin. Lab. Sci., 2000, V. 30, No. 4, p.354365.

8. Boaghi E., Capcanari T., Mija N., Deseatnicova O., Opopol N. The evolution of food product consumption in Republic of Moldova in the demographic transition period. In: J. of Engineering Science, 2018, V. 25, No. 4, pp. 74-81. 
9. Camara F., Amaro M.A., Barbera R. Bioaccessibility of minerals in school meals: Comparison between dialysis and solubility methods. In: Food Chem., 2005,V. 92, No. 5, p. 484-489.

10. Sturza R., Ghendov-Mosanu A. (2021). Food, nutrition and health in Moldova. In: Nutritional and Health Aspects of Food in the Balkans, CH015: 249-262. Academic Press, Elsevier ed. pp. 249-262.

11. Sotelo A., Gonsalez-Osnaya L. Role of oxalate, phytate, tannins and cooking on iron bioavailability from foods commonly consumed in Mexico. In: Int. J. Food Sci. \&Nutr., 2010, V. 61, No. 1, p.29-39.

12. Nelson M., Poulter J. Impact of tea drinking on iron status in the UK, In: J. Human Nutr.\& Diet., 2004, V.17, No.1, p. 43-44.

13. Aquilera I. Iron status in a population of Spanish schoolchildren. In: Food/Nahrung, 1994, V. 38, No. 2, pp. 38-46.

14. FAO/WHO. World Declaration on Nutrition. Second International Conference on Nutrition. Rome, 19-21 November, 2014.

15. Clarke G.M., Higgins T.H. Laboratory investigation of hemoglobinopathies. In: Clin. Chem., 2000, V.46, No. 6, p. 39-45.

16. Mija N. Iron-binding protein evaluation in foods of animal origin. Theses and oral communication on the Special Session at the International Conference on Nutrition, Food Science and Technology. 14-15 Nov., 2018, Rome, Italy. Joint Event on 20 years of excellence in international meetings conducted by alliedacademies.com. In: Archives of General Internal Medicine, nov. 2018, V.2, p. 23. ISSN: 2591-7951. DOI: 10.4066/2591-7951-C6-017.

17. Sturza R., Gudumac V., Deseatnicova O., Ghendov-Mosanu A. Dietary improvement of the iron statute of the rats with experimental anemia. In: One Health \& Risk Management, 2021 V. 2 No. 1, p. 13-27.

18. Sun J., Zhang L. et.al. Effect of dietary intervention treatment on children with iron deficiency anemia. A meta-analysis. In: Lipids in Health and Desease, 2018, V. 17, No. 5, p. 108-114.

19. Miller D.D., Schricker B.R., Rasmussen R.R. An in vitro method for estimation of iron avaibility from meals. In: Am. J. Clin. Nutr., 1981, 34 (10), pp. 2248-2256.

20. Kosse J.S., Yeung A.C., Miller D.D. A rapid method for iron determination in fortified foods. In: Food Chemistry, 2001, 75, No. 11, p. 371-376.

21. ISO 8070:2007. Milk and milk products. Determination of calcium, sodium, potassium and magnezium contents. Atomic absorbtion spectroscopic method.

22. Korn M.G., Welz B. Sample preparation for the determination of metals in food samples using spectroanalytical methods - A review. In: Applied Spectroscopy Reviews, 2008, V. 43 No. 2, p. 67-92.

23. ISO 13730:1999. Meat and meat products. Determination of total phosphorus content.

24. Wu P., Tian J.C., Walker C.E., Wang F.C. Determination of phytic acid in cereals. A brief review. In: Int. J. Food Sci. \& Tech., 2009. V. 44, No. 9, p. 1671-1676.

25. ISO 6059:1984. Water. Determination of calcium and magnezium - EDTA titrimetric method.

26. Sturza R. Modern principles of food analysis. Ch.: UTM, 2006.- 310 p.

27. ISO 6557-1:2016. Fruits, vegetables and derived products. Determination of ascorbic acid.

28. Food and Nutrition Board, Institute of Medicine. Dietary references intakes, iron. Washington D.C.: National Academy Press, 2001 - p. 290-393.

29. Sunitha S.V. Bioavailability of Iron in selected cereal based preparation, an in vitro study. In: Food/Nuhrung, 1996, V.39, No. 5-6, p. 73-77.

30. Sturza R., Deseatnicova O., Gudumac V. Iron deficiency in food and eradication methods. Ch.: UTM, 2008.- 223 p.

31. Dupouy E., Gurinovici M. Sustainable food systems for healthy diets in Europe and Central Asia: Introduction to the special issue. In: Food Policy, 2020, V. 96, No. 8, e101952.

32. Hyska J., Burazeri G., Menza V., Dupouy E. Assesing nutritional status and nutritional-related knowledge, attitudies and practices on Albanian schoolchildren to support school food and nutrition policies and programmes. In: Food Policy, 2020, V. 96. No. 10, e101888.

33. Ciobanu C., Suhodol N., Deseatnicova O. The bioavailability of Iron from Pastries with Added Rosehip. In: The $8^{\text {ht }}$ international symposium EuroAliment, Book of abstracts, 2017. Galaţi, Romania.

34. Garg A., Abrol P. Effect of vitamin A supplementation on hematopoiesis in children with anemia. In: Ind. J. of Clin. Biochem., 2005, V.20, No. 3, p. 85-86.

35. Garcia M.M. Intake of Maillard research products reduced iron bioavailability in male adolescents. In: Molecular Nutrition \& Food Research, 2009, V. 53, No. 12, pp. 163-169. 
36. South P.K., House W.A., Miller D.D. Tea consumption does not affect iron absorption in rats unless tea and iron are consumed together. In: Nutr. Res., 1997, V. 17, No. 1, p. 1303 - 1305.

37. Torre M., Rodrighuez A.R. Effects of dietary fiber and phytic acid on mineral avaibility. In: Food Sci. Nutr., 1991, V. 11, No. 1, p. 11 - 12.

38. Hunt J.R. Algorithms for iron and zinc bioavailability. In: Int. J.Vitam. Nutr. Res., 2010, V.80, No. 5, p. $257-262$.

39. Hazell T., Johnson I.T. In vitro estimation of iron avaibility from a range of plant foods: influence of phytate, ascorbate and citrate. In: British Journal of Nutrition, 1987, V. 57 No. 10, p. 223 - 233.

40. Monsen E.R. Iron nutrition and absorption. Dietary facts which impact iron bioavailability. In: J. Am. Diet. Assoc., 1988, V. 88, No. 5, p. 786 - 790.

41. Schiff W.J. Nutrition for healthy living. London: Macmillan Education LTD, 2019 - 460 p.

42. Hallberg L., Hulthen L. Iron stores in man relation to diet and requirements. In: Eur. J.Clin. Nutr., 1998, V. 52, No. 2, p. $623-631$.

43. Morck T.A. Lynch S.R., Cook J.D. Inhibition of food iron absorption by coffee. In: Am. J. Clin. Nutr., 1983. V. 37, No. 3, p. 416-420.

44. Deseatnicova E., Şorici G., Berlinschi I., Gropa L., Deseatnicova O. Calcium, vitamin D and some others mineral food intake in women from the Republic of Moldova. In: Osteoporosis International with other metabolic bone diseases, 2018. V. 29, No. 1, p. 453. (IF=3,591)

45. Reddy M.B., Cook J.D. Effect of calcium intake on non-heme iron absorption from meal composition. In: Am. J. Clin. Nutr., 1997, V. 65, No. 3, p.1820-1825.

46. Whiting S.J. The inhibitory effect of dietary calcium on iron bioavailability. A cause of concern. In: Nutr.Res., 1995, V. 15, No. 6, p. 72 - 77.

47. Lynch S. The effect of calcium on iron absorption. In: Nutr.Res. Rev., 2001, V.13, No. 2, p. 141 - 158.

48. Cook J.D., Dassenko S.A. Calcium suplimentation: effect on iron absorption. In: Am. J. Clin. Nutr., 1991, V. 49, No. 5, p. 103 - 106.

49. Deseatnicova E., Şorici G., Berlinschi I., Gropa L., Deseatnicova O. Calcium, vitamin D and some others mineral food intake in women from the Republic of Moldova. In: Osteoporosis International with other metabolic bone diseases, 2018. V. 29, No. 1, p. 453.

50. Pepper S.E., Borkowski M. Determination of ferrous and ferric iron in aqueous biological solutions. In: Analytica Chimica Acta, 2010, 663 (X), pp. 172 - 177.

51. Sturza R., Gudumac V., Deseatnicov O., Ciobanu C. The influence of bread making procedure used for fortified bread production on the iron statute of the rats with experimental anemia. Scientific Study \& Research, Vol. X (1), 2009, pp 53 - 66. 